Jurnal Konstruksi Hukum | ISSN: 2746-5055

Vol. 2, No. 2, Mei 2021, Hal. 361-366| Tersedia online di

https://www.ejournal.warmadewa.ac.id/index.php/jukonhum

DOI: https://doi.org/10.22225/jkh.2.2.3256.361-366

\title{
HUKUMAN MATI DALAM TINDAK PIDANA NARKOTIKA DITINJAU DARI PERSPEKTIF HAK ASASI MANUSIA (STUDI PUTUSAN MAHKAMAH KONSTITUSI NOMOR 2-3/PUU-V/2007)
}

\author{
Christofel Brayn Leonard Totomutu, I Nyoman Gede Sugiartha, I Made Minggu Widyantara \\ Fakultas Hukum, Universitas Warmadewa, Denpasar - Bali, Indonesia \\ christofeltotomutu@gmail.com, nyomansugiartha14@gmail.com, mademinggu21@gmail.com
}

\begin{abstract}
Abstrak
Hukuman mati diatur dalam beberapa peraturan perundang-undangan di Indonesia, khususnya tindak pidana narkotika yang diajukan permohonan pengujian undang-undang terhadap Undang-Undang Dasar. Tipe penelitian yang dipakai dalam penelitian ini yakni tipe penelitian hukum normatif. Sumber data yang dipakai dalam yakni bahan hukum primer, yang dalam penelitian ini diangkat dari sumber aslinya Undang-undang. Bahan hukum sekunder yaitu bahan yang diangkat dari buku, jurnal, dan karya ilmiah dan bahan hukum tersier. Teknik pengumpulan bahan hukum dalam penelitian ini adalah teknik pengumpulan bahan hukum/bacaan, yang dilakukan dengan cara mengumpulkan bahan yang ada atau studi dokumen dari peraturan perundang-undangan yang ada serta putusan hakim mahkamah konstitusi dan dijelaskan kalimat perkalimat dengan menggunakan metode pengolahan bahan hukum secara sistematis. Tujuan penelitian ini untuk mengetahui hukuman mati tindak pidana narkotika ditinjau dari sisi Hak Asasi Manusia serta mengetahui pertimbangan hakim terhadap hukuman mati tindak pidana narkotika di Indonesia berdasarkan putusan mahkamah konstitusi nomor 2-3/PUUV/2007. Hasil penelitian mengungkapkan bahwa hukuman mati tindak pidana narkotika telah tercantum dalam pasal maupun undang-undang namun disisi lain terdapat pertimbangan majelis hakim terkait kasus hukuman mati tindak pidana narkotika bahwa hukuman mati dalam Undang-undang Narkotika tidak bertolak belakang dengan hak asasi dan hak hidup manusia sebagaimana dalam UUD NRI 1945 dikarenakan jaminan hak asasi dan hak hidup dalam UUD NRI 1945 tidak menganut asas mutlak.
\end{abstract}

Kata Kunci: Hukum, Narkotika, Pidana

\begin{abstract}
The capital punishment is regulated in several laws and regulations in Indonesia, in particular for narcotics crimes that are submitted for judicial review against the Constitution. The type of research used is the type of normative. The sources of the data used in this research are primary, which are taken from the original source of the law and secondary materials are materials derived from books, journals and scientific works and tertiary legal materials. The technique of collecting data in this research is carried out by collecting existing materials or studying documents from existing laws and regulations as well as the decisions of the constitutional court judges and explaining the sentence by using the legal material processing method systematically. The purpose of this research was to determine the capital punishment for narcotics crime in terms of human rights and to find out the judges considerations on the capital punishment for narcotics crime in Indonesia based on the decision of the constitutional court number 2-3/PUU-V/2007. The results of the research revealed that the capital punishment for narcotics crime has been stated in articles and laws, but on the other hand there is a consideration of the panel of judges regarding the capital punishment case for narcotics crime that the capital punishment in the Narcotics Law does not contradict human rights and human rights as in the 1945 Constitution of the Republic of Indonesia because the guarantee of human rights and the right to life in the 1945 Constitution of the Republic of Indonesia does not adhere to absolute principles.
\end{abstract}

Keywords: Law, Narcotics, Criminal

\section{PENDAhuluan}

Indonesia sebagai negara hukum yang artinya hukum menjadi sesuatu yang mengatur dalam segala ranah kehidupan berbangsa dan bemegara. Point-point yang tercantum di alinea ke-4 pembukaan UUD NRI 1945 dapat terwujud apabila penekanan integritas orang dalarn mengelola sumber daya negara dengan tidak mudah diintervensi oleh pihak-pihak dalam kepentingan, dikarenakan perkembangan tindak pidana di Indonesia semakin meningkat. Tindak Pidana adalah suatu tindakan melanggar hukum seorang atau beberapa orang dengan maksud tertentu dilarang oleh aturan hukum, yang dimana larangan tersebut mengandung ancaman. 
Pengertian yang diberikan oleh para ahli hukum mempunyai tolak ukur tersendiri, dimana pengertian ini acap kali membingungkan karena susunan pemikiran para ahli untuk orang yang baru akan belajar hukum dan atau orang-orang awam, sehingga perkenalan pertama dimulai dengan salah paham, karena tidak mungkin memberikan definisi tentang hukum yang sungguh-sungguh dapat memadai sesuai dengan kenyataan (Apeldoorn, 2004:1).

Kodifikasi dan unifikasi hukum pidana dimaksudkan untuk menyatukan semua aturan hukum pidana dalam satu kitab undang-undang agar terwujud sistematika hukum yang mudah dipahami dan ditegakkan. Undang-undang Nomor 35 Tahun 2009 tentang Narkotika merupakan suatu produk hukum yang telah dikodifikasi di Indonesia. Pengaturan narkotika bertujuan untuk menjamin ketersediaan guna kepentingan kesehatan dan ilmu pengetahuan, mencegah penyalahgunaan narkotika, dan untuk pemberantasanperedaran gelap narkotika (Lintong, 2018:18).

Hak asasi manusia adalah sebuah konsep hukum dan normatif yang menyatakan manusia memiliki hak yang melekat pada dirinya sebagai makhluk ciptaan Tuhan paling sempurna. Ham berlaku kapanpun, dimanapun, dan kepada siapapun, sehingga bersifat universal. Merujuk pada Pengujian Undang-undang terhadap UUD NR1 dalam Putusan MK Nomor 2-3/PUU-V/2007 adalah mengenai hak hidup dalam hak asasi manusia secara universal yang diajukan oleh para pemohon.

Paradigma masyarakat menimbulkan pro dan kontra terhadap paradigma masyarakat mengenai hukuman mati dan hak hidup. Memang sejatinya hak hidup itu dijarnin oleh negara didalam hukum, namun perlu juga memahami tolak ukur atas hak asasi setiap orang sejauh mana dan sejauh mana juga hak hidup manusia dapat dipertahankan oleh suatu negara.

Pidana mati bagi terpidana narkotika merupakan adalah perlidungan HAM bagi setiap masyarakat dikarenakan kasus narkotika merupakan salah satu extra ordinary crime yang telah merugikan bangsa dalam jumlah yang besar secara materiil atau immaterial (Sembel et al., 2020). Menurut (Arfa et al., 2020) Narapidana yang menolak penerapan hukuman mati biasanya bertolak dari prinsip umum yang terdapat dalam UUD 1945 dan Undang-Undang mengenai hak asasi manusia. Sementara, narapidana yang mengusung hukuman mati lebih melihat akibat yang ditimbulkan oleh penyalahgunaan narkotika yang menimbulkan korban yang teramat luas. Oleh karena itu, menyikapi pro dan kontra terhadap penerapan hukuman bagi bandar dan pengedar narkotika diperlukan pandangan dan sikap yang arif sehingga diperoleh kesepakatan mengenai penerapan pidana mati tersebut, terutama terhadap pengedar. Setiap warga negara berhak untuk mempertahankan atau membela diri terhadap setiap ancaman atau serangan yang tertuju pada keselamatan jiwanya. Hal ini merupakan hak asasi manusia, maka perampasan nyawa oleh Negara berupa penjatuhan pidana mati pada hakikatnya merupakan pelanggaran HAM apabila dilakukan sewenang-wenang, tanpa dasar yang sah menurut hukum yang berlaku (Anugrah et al., 2020). Namun disisi lain Ikhwanuddin (2018) menjabarkan bahwa majelis hakim konstitusi menyatakan hukuman mati dalam UU Narkotika tidak bertentangan dengan hak hidup yang dijamin UUD 1945 karena jaminan hak asasi manusia dalam UUD 1945 tidak menganut asas kemutlakan.

Berdasarkan penjelasan diatas, maka dapat dirumuskan tujuan dari penelitian ini untuk mengetahui hukuman mati tindak pidana narkotika ditinjau dari sisi Hak Asasi Manusia serta mengetahui pertimbangan hakim terhadap hukuman mati tindak pidana narkotika di Indonesia berdasarkan putusan mahkamah konstitusi nomor 2-3/PUU-V/2007.

\section{METODE PENELITIAN}

Tipe yang digunakan dalam penelitian ini yakni tipe penelitian hukum normatif. Bahan hukum yang dipakai dalam penyusunan yakni bahan hukum primer, yang dalam penelitian ini diangkat dari sumber aslinya Undang-undang, bahan hukum sekunder yaitu bahan yang diangkat dari kajian bacaan yaitu dengan cara membaca buku-buku, jurnal-jurnal, dan karya ilmiah lainnya yang berhubungan dengan hukuman mati dalam tindak pidana narkotika ditinjau dari perspektif hak asasi manusia dan bahan hukum tersier berupa karnus-karnus, baik Kamus Besar Bahasa Indonesia, Kamus Bahasa lnggris, maupun Kamus Latin, internet. Teknik pengumpulan bahan hukum dalam penelitian ini adalah teknik pengumpulan bahan hukum/bacaan, yang dilakukan dengan cara mengumpulkan bahan 
yang ada atau studi dokumen dari peraturan perundang-undangan yang ada serta putusan hakim mahkamah konstitusi. Adapun ketika bahan hukum terkumpul, maka bahan hukum tersebut akan digambarkan dan dijelaskan kalimat per kalimat dengan menggunakan metode pengolahan bahan hukum secara sistematis.

\section{HASIL DAN PEMBAHASAN}

\section{Hukuman Mati Tindak Pidana Narkotika Dengan Hak Asasi Manusia}

Hukuman mati merupakan penjatuhan hukuman terberat dari semua jenis pidana pokok, yang dimana diancamkan terhadap unsur-unsur tindak pidana dalam pasal-pasal tertenru saja, karena pelaksanaannya langsung ditujukan terhadap hak hidup bagi pelanggar yang sesungguhnya hak ini hanya berada di tangan Tuhan (Chazawi, 2019:29). Hukuman mati itu sendiri adalah suatu hukuman yang diberikan terhadap seseorang atau beberapa orang yang dijatuhkan vonis oleh pengadilan sebagai bentuk terberat dari akibat perbuatannya melawan hukum.

Hukuman mati di Indonesia terdapat dalam Pasal 10 KUHP Pasal 11 KUHP. Dalam hal hukuman mati terhadap pelaku tindak pidana narkotika pada awalnya terdapat dalam Pasal 113 ayat (2), yang dimaksudkan kepada pelaku peredaran gelap narkotika itu sendiri. Karena pada umumnya di Indonesia, pengaruh narkotika dikalangan masyarakat sangat meresahkan baik dari segi kesehatan, ekonorni, sosial, bahkan yang timbul kedepannya dari efek kecanduan penggunaan narkotika dan bahkan berakibat pada kelumpuhan ataupun kematian. Maka tolak ukur hukuman mati diterapkan kepada mereka dalam peredaran gelap narkotika skala nasional maupun internasional. Hukuman mati selalu diancarnkan secara alternatif dengan pidana pokok lain. Apabila dalam fakta yang dikehendaki bahwa terdakwa terbukti bersalah melakukan kejahatan yang diancam dengan hukuman mati, maka hakim dapat menjatuhkan hukuman alternatif lainnya. Dalam keadaan tertentu hukuman mati dapat ditangguhkan sampai presiden memberikan kiat Eksekusi.

Jika dilihat dari tujuan pemidanaan, pidana mati belum mampu berfungsi dilihat dari tujuan pemidanaan belum mampu berfungsi sebagai sarana utama mengatur, menertibkan dan memperbaiki masyarakat. Maka ada baiknya pemerintah merumuskan peraturan perundang-undangan hukum pidana khususnya pidana mati dan apakah pidana mati masih diperlukan dalam undang-undang narkotika di masa yang akan datang (Wardana, 2014).

Adapun tolak ukur dari negara untuk mempertahankan hukuman mati supaya masyarakat memperhatikan bahwa pemerintah tidak menginginkan adanya gangguan terhadap ketentraman umum. Hukuman rnati perlu dipertahankan untuk penegakan hukum dari perbuatan pelaku kejahatan yang mengancam ketentraman umum.

Teori pemidanaan dibagi menjadi 3, yakni :

1. Absolut atau pernbalasan (verge/dings theorien): Pemidanaan ditujukan untuk dasar pembalasan dari perbuatannya.

2. Relatif atau tujuan (doe/ theorien\} : Teori ini mengedepankan tujuan pemidanaan adalah untuk rnengubah pola pikir pelaku secara rohani dan jasmani menjadi orang yang lebih baik lagi sehingga diupayakan tidak melakukan sifat tercel a daJam masyarakat dan hukum.

3. Gabungan (verenigings theorien) : Teori ini menitik beratkan pada pembalasan namun mengutamakan ketertiban masyarakat terjamin.

Adapun yang perlu dibahas yaitu cara pelaksanaan hukuman mati yang diatur dalam PNPS

No. 2 Tahun 1964 tentang Tata Cara Pelaksanaan Pidana Mati yang dijatuhkan oleh Pengadilan di Lingkungan Peradilan Umum dan Militer. Dalam Pasal 1 menyatakan penerapan hukuman mati dijaJani dengan cara ditembak sampai mati, yang mengubah pelaksanaan awal hukuman mati menurut Pasal 11 KUHP.

Hal ini dilakukan sebagai upaya eksistensi dari hukuman mati dengan tolak ukur bahwa hukuman mati dengan cara digantung lebih tidak manusiawi karena rnenimbulkan rasa sakit dan derita yang lebih panjang terhadap terpidana saat tergantung. Namun apabila ditembak yang menjadi tolak ukur adalah agar terpidana tidak memerlukan waktu lama dalam merasakan sakit sehingga dapat menjalani hukuman mati dengan tidak rnenderita terlebih dahulu seperti cara penerapan hukuman mati lainnya. 


\section{Pertimbangan Hakim Terhadap Hukuman Mati Tindak Pidana Narkotika di Indonesia Berdasarkan Putusan Mahkamah Konstitusi Nomor 2-3/PUU-V/2007}

Sebelurn membahas mengenai pertirnbangan hakirn, rnaka akan diuraikan mengenai pendapat para ahli terlebih dahulu. Pandangan-pandangan yang ada ini merupakan pemikiran konkrit sebagai bagian yang berhubungan dengan realistis hukuman mati di Indonesia, antara Iain:

\section{a. Pandangan tidak setuju penerapan hukuman mati di Indonesia}

Prof JE Sahetapy menyatakan ketidaksetujuannya terhadap hukuman mati dengan tujuan pembalasan dan menakut-nakuti. Menurut beliau, pemidanaan baiknya bertujuan "pernbebasan". Hukuman mati memang membebaskan secara mental dan spiritual tetapi bukan berarti melepaskan cara berpikir dan gaya hidupnya yang lama (Sahetapy, 1979:216-217).

Roeslan Saleh menyatakan pertama, bahwa vonis pengadilan oleh hakim tidak dapat diperbaiki apabila suatu saat diketahui ada kesalahan pemeriksaan atau cara lainnya. Poin kedua, mengacu pada falsafah pancasila, maka hukuman mati itu bertentangan dengan perikemanusiaan.

\section{b. Pandangan setuju penerapan hukuman mati di Indonesia}

Prof. Yusril Ihza Mahendra (MenHum 1999-2004) mempunyai pendapat setuju, karena bagi dia terhadap kejahatan luar biasa oleh negara tidak dapat ditolerir, karena berhubungan dengan ketentraman negara. Achmad Ali mengemukakan pendapat, hukuman mati sangat diperlukan dan diterapkan melalui spesifikasi dan selektifitas. Spesifikasi untuk kejahatan luar biasa. Dan selektif adalah terpidana harus sesuai dengan fakta-fakta persidangan meyakinkan hakirn bahwa pelakunya adalah dirinya. Sebagaimana dalam putusannya hakim mahkamah konstitusi meyimpulkan, hukuman mati dalam Undang-undang Narkotika pada waktu itu tidak bertolak belakang dengan hak asasi dan hak hidup manusia sebagaimana dalam UUD NRI 1945 dikarenakan jaminan hak asasi dan hak hidup dalam UUD NRI 1945 tidak menganut asas mutlak.

Dalam hal penerapan hukuman mati, Mahkamah berkesimpulan negara tidak melanggar perjanjian internasional apapun, termasuk Konvensi lntemasional Hak Sipil dan Politik (ICCPR). Karena sejatinya Pasal 6 ayat (2) ICCPR, memperbolehkan penerapan hukuman mati namun tetap dalam pengelompokan kejahatan tertentu yang serius. Keputusan pembuat undang-undang telah sejalan dengan perjanjian intemasional lainnya mengenai narkotika dan psikotropika. Tolak ukur dan kehati-hatian unsur-unsur hukuman mati dalam undang-undang adalah dengan penyusunan dengan penuh kehati-hatian karena tidak diancamkan kepada semua ketenruan. Sebab hanya dicantumkan kepada pembuat atau pelaku peredaran gelap narkotika yang besar, luas, dan sistematis.

Hukum kodrat yakni hukum yang lahir dari kegiatan akal budi manusia (Suseno, 1987:187). Berkaitan dengan penjaminan Hak Asasi Manusia di Indonesia, diatur dalam konstitusi UUD NRI 1945 Pasal 28A-Pasal 281 ayat (1) akan tetapi hak asasi seseorang, tersebut temyata juga dibatasi dalam konstitusi negara, dalam Pasal 281 ayat (2).

Berdasarkan pasal ini, hukuman mari sering dipandang sebagai sesuatu yang tidak melanggar hak asasi rnanusia karena dianggap sesuai dengan isi konstirusi negara. Hukuman mati pada akhirnya dipandang sebagai alat untuk melindungi seluruh rakyat Indonesia dari penjahat-penjahat berbahaya dalam kejahatan tertentu atau kejahatan khusus (Lex Specialis).

\section{SIMPULAN DAN SARAN}

\section{Simpulan}

Pengaturan mengenai hukuman mati sejatinya diatur dalam KUHP dan setidaknya ada 6 (enarn) peraturan perundang-undangan khusus yang mengatur mengenai hukuman mati. Dalam Undangundang Nomor 35 Tahun 2009 tentang Narkotika secara spesifik terdapat dalarn Pasal ketentuan pidana Penerapan unsur-unsur yang terdapat dalam pasal-pasal tersebut disusun sedemikian secara sisternatis dan telah dikodifikasi merupakan suatu prinsip kehati-hatian dari pembuat undang-undang yang menghasilkan produk hukum narkotika. Penerapan hukuman mati tidak diterapkan dalam semua 
pasal yang ada dalam Bab XV tentang Ketentuan Pidana, hal ini ditujukan selain prinsip kehati-hatian tetapi juga bertolak pada penjaminan negara terhadap hak asasi manusia yang berlaku secara universal dan mengacu juga pada Undang-undang Nomor 12 Tahun 2015 yang memberikan mengenai pengaturan hukuman mati terhadap suatu kejahatan luar biasa (extraordinary crime). Pertimbangan Majelis Hakim Konstirusi dalam persidangan Judicial Review dalam aman putusan menyatakan menolak dan tidak dapat diterima perrnohonan dari pemohon, dengan mengacu pada Pasal 28J ayat (2). Tolak ukur yang dipakai yakni, negara menjamin hak hidup seseorang sebagai mana dalam konstitusi. Namun hak hidup itu sendiri mempunyai batasan, sepanjang perbuatan itu tidak merampas dan/atau mengurangi hak hidup orang lain. Ketika hak hidup orang lain dilanggar oleh seseorang, maka negara hadir dalam upaya kedaulatannya untuk mengembalikan hak hidup yang dimiliki oleh korban.

\section{Saran}

Saran dari keseluruhan yang dapat kemukakan dalam mengkaji penelitian ini adalah sebagai berikut :

a. Bagi pemerintah, Paradigma mengenai penerapan hukuman mati dan hak hidup di masyarakat mengalir dengan banyaknya pandangan negatif, sehingga masyarakat mencema pandangan hukum hanya dengan satu sisi saja dan tak sering menggunakan emosi yang Jabil. Untuk itu perlu adanya penggiringan opini yang baik untuk mengatur paradigma masyarakat dari pembuat, penegak, dan pelaksana hukum sedemikian rupa dan meningkatkan integritas dari orang-orang yang berkecimpung di dunia hukum. Di Indonesia peredaran narkotika masih sering dikendalikan melalui orang yang berada di dalarn Lembaga Pernasyarakatan, untuk iru proses penjagaan para narapidana perlu ditingkatkan yang diperbarengi oleh perekrutan penjaga lapas yang berintegritas tinggi. Dan bagi masyarakat, Penerapan hukuman mati masih diperlukan di Indonesia meskipun sejatinya tidak membuat peredaran gelap narkotika di Indonesia terhenti, tetapi hukuman mati mencegah kemungkinan lebih besar dari upaya peredaran gelap narkotika di Indonesia. Paradigma yang timbul di masyarakat mengenai hukuman mati harus dilihat dari dua sisi (positif dan negatif) yang dimana dalam membahas ini juga harus serta merta didiskusikan dengan ahli atau pakar hukum.

b. Bagi pelaku tindak pidana narkotika, dengan adanya penerapan hukuman mati diharapkan mempunyai efek jera sehingga dapat membantu pemerintah dalam memberantas peredaran gelap narkotika dalam masyarakat. Pun mengenai pelaku yang menjalani masa tahanan agar supaya dalam lembaga pemasyarakatan dapat memaknai akibat dari perbuatannya yang di bina di dalam lapas, sehingga yang diharapkan apabila sudah melewati waktu masa tahanan dapat kembali ke masyarakat dengan menjadi masyarakat yang lebih baik serta meninggalkan dunia peredaran narkotika di Indonesia.

\section{DAFTAR PUSTAKA}

Anugrah, R., Desril, R., \& Disemadi, H. S. (2020). Pidana Mati Terhadap Kejahatan Narkotika Ditinjau dari Pasal 28I Ayat (1) UUD NRI 1945. Jurnal KERTHA WICAKSANA: Sarana Komunikasi Dosen Dan Mahasiswa, 14(2), 110-117.

Apeldoorn, LJ. Van. (2004). Pengantar Ilmu Hukum, Cet.30. Jakarta.

Arfa, N., Nur, S., \& Monita, Y. (2020). Tinjauan Yuridis Penerapan dan Pelaksanaan Hukuman Mati Terhadap Pelaku Tindak Pidana Pengedar Narkotika Berdasarkan Undang-Undang Nomor 35 Tahun 2009 Tentang Narkotika. Jurnal Sains Sosio Humaniora, 4(2), 526-537.

Chazawi, Adami. (2019). Pelajaran Hukum Pidana, Cet.9. Raja Grafindo Persada. Jakarta.

Ikhwanuddin. (2018). Tinjauan Yuridis tentang Penjatuhan Hukuman Mati Terhadap Perantara Jual Beli Narkotika yang Disertai dengan Pencucian Uang (Studi Putusan Nomor 594/pid.sus/2015/pn.Tjb). Jurnal Prointegrità, 2(1), 49-69. 
Lintong, Abraham Mononutu. (2018). Hukuman Mari Di Indonesia Suatu Kajian Etika Kristen, Cet.1, Percikan Hati, Tomohon.

Sahetapy, J.E. (1979). Ancaman Pidana Mari Terhadap Pembunuhan Berencana. Alumni Bandung, Bandung.

Sembel, N. S. G., Kumendong, W. J., \& Waha, C. J. J. (2020). Penerapan Pidana Mati Terhadap Pengedar Narkotika Ditinjau dari Perspektif Hak Asasi Manusia. Jurnal Lex Et Societatis, 8(3), $5-15$.

Suseno, Magnis. (1987) Etika Politik (Prinsip-Prinsip Moral Dasar Kenegaraan Modern). Gramedia, Jakarta.

Wardana, I. W. (2014). Kebijakan Formulasi Pidana Mati dalam Tindak Pidana Narkotika di Indonesia. Jurnal IUS Kajian Hukum Dan Keadilan, 2(2), 265-284. 